\title{
Konsep Kesiapan Siswa dalam Mengerjakan Tugas
}

\author{
Dinda Jengtika Reski ${ }^{1}$, Asmidir Ilyas ${ }^{2}$ \\ Universitas Negeri Padang, Universitas Negeri Padang \\ *) Correspondence e-mail: dindajengtikar@gmail.com asmidir_ilyas@konselor.org
}

\begin{abstract}
Kesiapan belajar merupakan keseluruhan kondisi seseorang yang membuatnya siap untuk memberikan respon atau jawaban di dalam proses pembelajaran. Proses pembelajaran akan berjalan dengan baik apabila disokong oleh beberapa hal antara lain: kesiapan untuk belajar, mengerjakan tugas, membaca, dan sebagainya. Salah satu yangmempengaruhi kesiapan belajar dan membuat tugas adalah kesiapan psikis seseorang. Kesiapan psikis tersebut yaitu kesiapan psikis untuk belajar mandiri yang melipti senang belajar, belajar dengan kemauan sendiri, pemahaman diri, tanggung jawab dalam belajar atau mengerjakan tugas dan kreatif dalam membuat tugas atau kegiatan. Artikel ini mendeskripsikan tentang kesiapan siswa dalam mengerjakan tugas.
\end{abstract}

Keywords: Kesiapan siswa, mengerjakan tugas

Article History: Received on 15/01/2019; Revised on 15/02/2019; Accepted on 26/03/2019; Published Online: 30/03/2019 distribution, and reproduction in any medium, provided the original work is properly cited. (C2019 by author.

\section{Pendahuluan}

Kesiapan belajar mandiri dan mengerjakan tugas siswa yang tinggi akan membuat siswa siap untuk memberikan respon atau jawaban yang ada dalam pelajaran atau siap menerima pelajaran dengan baik. Sehubungan dengan itu Slameto (2010: 113) mengatakan kesiapan siswa sebagai keseluruhan kondisi seseorang yang membuatnya siap untuk memberikan respon ataupun jawaban dalam cara tertentu. Kesiapan belajar merupakan salah satu faktor yang mempengaruhi proses belajar seseorang. Selanjutnya Nasution (2005) mengemukakan kesiapan belajar adalah kondisi yang mendahului kegiatan belajar itu sendiri. Tanpa kesipan yang matang proses belajar tidak akan berjalan dengan baik.

Menurut Djamarah (2002) kesiapan belajar atau kesiapan dalam mengerjakan tugas mencangkup tiga aspek yaitu (1) kesiapan fisik, mental dan emosional. Kondisi fisik yang dimaksud adalah bagaimana kesiapan jasmani seseorang dalam belajar atau membuat tugas. Kondisi mental adalah keadaan yang berhubungan dengan kecerdasan seseorang. Sedangkan kondisi emosional adalah kondisi seseorang untuk dapat mengatur emosinya saat belajar atau membuat tugas dalam menjawab pertanyaanyang dianggapnya sulit. (2) kebutuhan motif dan tujuan, kebutuhan berarti segala sesuatu yang harus dipenuhinya dalam belajar atau membuat tugas atau rasa membutuhkan terhadap materi yang 
dipelajarinya. membutuhkan mendorong seseorang untuk siap belajar atau mengerjakan tugasnya. Sehingga kebutuhan sangat erat hubungannya dengan kesiapan belajar siswa atau kesiapan dalam mengerjakan tugasnya. (3) keterampilan, pengetahuan dan pengertian yang lain yang telah dipelajari.

Kesiapan siswa dalam belajar khususnya dalam mengerjakan tugas rumah sangat membantu siswa untuk meningkatkan hasil belajar terkait dengan materi pelajaran yang diberikan oleh guru. Menurut Djamarah (2006) tujuan pemberian tugas rumah akan membantu siswa lebih aktif belajar, baik aktivitas belajar kelompok atau individual, serta membina tanggung jawab dan disiplin peserta didik. Pemberian tugas rumah akan meningkatkan prestasi belajar siswa karna adanya pengulangan pembelajaran yang telah dipelajari disekolah.

\section{Tugas}

Tugas adalah suatu pekerjaan yang menuntut untuk dikerjakan sampai selesai. Siswa yang menyadari akan diberikan tugas oleh gurunya setelah ia menerima bahan pelajaran, dan berkonsentrasi terhadap pelajaran tersebut. dikhawatirkan mereka tidak dapat menyelesaikan tugas dengan baik dan benar. Dalam pemberian tugas diperlukan rentangan waktu yang seimbang sesuai dengan tingkat berat atau ringannya sifat tugas tersebut, sehingga siswa tidak merasa terburu-buru dalam mengerjakan tugas atau dikejar waktu penyelesaian tugas tersebut.

Pemberian tugas merupakan salah satu bentuk kerja nyata yang dilakukan siswa untuk lebih memahami penjelasan materi yang disampaikan oleh guru baik secara individual ataupun kelompok, tujuannya untuk meningkatkan kemampuan kognitif dan kreativitas siswa. Pemberian tugas yang diberikan secara teratur dapat menanamkan kebiasaan sikap belajar yang positif dan dapat juga memotivasi siswa untuk belajar secara mandiri. Siswa yang mengerjakan tugas dengan sungguh-sungguh akan memperoleh hasil belajar yang lebih baik. Sehubung dengan hal itu Menurut Sudjana (2011) kemampuan belajar merupakan kemampuan yang dimiliki oleh siswa setelah ia memperoleh pengalaman, pengetahuan belajar ditempat tertentu. Hasil belajar yang dimaksud lebih lanjut akan dijelaskan sebagai berikut:

\section{Hasil Belajar}

Pemberian tugas diberikan agar dapat memotivasi siswa dalam belajar, serta meningkatkan hasil belajar yang diperolehnya, apabila siswa memiliki kesiapan dalam belajar maka hasil yang akan diperolehnya akan tinggi, begitu juga dengan sebaliknya.hasil belajar tersebut akan dijelaskan lebih lanjut sebagai berikut:

\section{Informasi Verbal}

Informasi verbal baik lisan maupun tulisan, siswa yang cerdas baik secara lisana atau tulisan akan memperoleh hasil belajar yang tinggi.

\section{Keterampilan Intelektual}

Keterampilan intelektual yaitu kemampuan berfikir siswa dalam memahami konsep belajar, kognitif yaitu kemampuan siswa dalam menyalurkan aktivitas kognitifnya sendiri sesuai dengan fakta. 


\section{Sikap}

Sikap yaitu kemampuan menerima atau menolak terhadap objek tertentu. Keempat komponen tersebut diperoleh dengan cara yang berlainan, artinya masing-masing memerlukan keterampilan, dan langkah yang berbeda.

\section{Kelebihan dalam Pemberian Tugas}

Selanjutnya Djamarah (2002) menjelaskan ada beberapa kelebihan dalam pemberian tugas kepada siswa, yaitu: lebih merangsang siswa untuk belajar lebih tekun lagi baik secara individu atau kelompok, dapat mengembangkan kemandirian siswa diluar pengawasan dari guru, dapat menjalankan tanggung jawabnya sebagai siswa dan mengembangkan kreativitas yang dimilkinya.

\section{Kelemahan dalam Pemberian Tugas}

Di samping ada kelebihan juga ada kelemahan dalam pemberian tugas kepada siswa, antara lain: sulit mengontrol siswa dalam mengerjakan tugas yang diberikan guru yang dikerjakan langsung oleh siswa atau dikerjakan oleh orang lain. khusus tugas kelompok tidak semua anggota kelompok yang ikut aktif dalam mengerjakan tugas tersebut hanya sebagian saja, dan sebagian lagi tidak berpartisipasi dalam kelompok tersebut.

\section{Faktor yang Mempengaruhi Belajar}

Belajar dipengaruhi oleh beberapa faktor, Menurut Slameto (2013) faktor yang mempengaruhi belajar lebih lanjut akan dijelaskan sebagai berikut:

\section{Faktor Jasmaniah}

Faktor jasmaniah, yaitu bagian dari kesehatan. Proses belajar seseorang akan terganggu jika kesehatannya juga terganggu. Agar seseorang dapat belajar dengan baik haruslah mengusahakan kesehatan badannya tetap terjamin dengan cara istirahat yang cukup.

\section{Faktor Psikologis}

Faktor psikologis meliputi: perhatian, untuk dapat menjamin hasil belajar yang baik maka siswa harus mempunyai perhatian terhadap bahan yang dipelajarinya. Minat, besar pengaruhnya terhadap belajar karna jika bahan pelajaran tidak sesuai dengan minat siswa maka tidak ada lagi daya tarik bagi siswa tersebut untuk belajar. Kesiapan, merupakan kesediaan untuk memberi respon terhadap apa yang dipelajari.

\section{Faktor Kelelahan}

Faktor kelelahan, kelelahan pada seseorang sulit untuk dipisahkan tetapi dapat dibedakan menjadi dua macam yaitu kelelahan jasmani dan kelelahan rohani (bersifat psikis) cara menghilangkan kelelahan yaitu tidur, istirahat, mengusahakan variasi dalam belajar, olahraga, rekreasi dan ibadah yang teratur.

\section{Kesiapan}

Kesiapan belajar akan berpengaruh pada prestasi belajar siswa. Menurut Tirtonegoro (1984) prestasi merupakan penilaian hasil kegiatan belajar siswa yang dinyatakan dalam bentuk simbol, angka atau huruf yang dicapai oleh siswa dalam 
periode tertentu. Sehubung dengan hal itu Mulyani (2013) mengemukakan siswa yang tidak memiliki kesiapan dalam belajar cenderung mendapatkan hasil belajar yang rendah. Sebaliknya siswa yang memiliki kesiapan belajar yang baik akan mendapatkan hasil belajar yang baik juga, sehingga dapat dikatakan tinggi rendahnya hasil belajar siswa dapat dilihat dari kesiapan belajar yang dimiliki selama proses belajar. Kesiapan merupakan keseluruhan kondisi seseorang yang membuatnya siap untuk memberi respon atau jawaban dalam cara tertentu terhadap suatu situasi.

\section{Faktor-faktor yang Mempengaruhi Belajar}

Faktor-faktor yang mempengaruhi belajar menurut Slameto, 2013 salah satunya yaitu penyesuaian kondisi pada suatu saat akan berpengaruh pada respon yang diberikan. Kondisi ini mencangkup tiga aspek yaitu: kondisi fisik, kebutuhan, dan keterampilan. Ketiga aspek tersebut akan mempengaruhi atau jadi kecendrungan untuk berbuat sesuatu. Lebih lanjut akan dijelaskan sebagai berikut:

\section{Kondisi Fisik}

Dalam kondisi fisik tersebut tidak termasuk kematangan. Kondisi fisik yang dimaksud misalnya kondisi fisik yang temporer (lelah, keadaan, alat indra).

\section{Kondisi Mental}

Kondisi mental menyangkut kecerdasan, kecerdasan dalam hal ini akan mempengaruhi hasil belajar yang akan diperoleh oleh siswa.

\section{Kondisi Emosional}

Kondisi emosional juga mempengaruhi kesiapan untuk berbuat sesuatu, hal ini adanya hubungan dengan motif (hadiah, atau hukuman) dan itu akan berpengaruh terhadap kesiapan untuk belajar. Hubungan ketiga aspek tersebut akan dijelaskan leboh lanjut.

\section{Hubungan Ketiga Aspek dalam Belajar}

Hubungan ketiga aspek tersebut adalah, sebagai berikut: Kebutuhan ada yang disadari dan ada yang tidak disadari, Kebutuhan yang tidak disadari akan mengakibatkan tidak adanya dorongan untuk berusaha, Kebutuhan mendorong usaha, dengan kata lain timbul motif, Motif tersebut diarahkan ke pencapaian tujuan

Kebutuhan yang disadari mendorong usaha atau membuat seseorang siap untuk berbuat, sehingga jelas ada hubungannya dengan kesiapan. Kebutuhan akan sangat menentukan kesiapan belajar. Siswa sebelum mempelajari permulaan ia belum siap untuk belajar berikutnya, sehingga ada prasyarat dan kosyarat dalam belajar.

\section{Prinsip yang Terkait dengan Belajar} berikut:

Beberapa prinsip yang terkait dengan belajar menurut Slameto (2013) sebagai

Seorang individu akan dapat belajar dengan sebaik-baiknya apabila tugas ynag diberikan berhubungan erat dengan kemampuan minat dan latar belakangnya.

Kesiapan belajar harus dilakukan dengan pengkajian kemampuan awal siswa sebelum kegiatan pembelajaran dilaksanakan.

Jika seorang individu kurang memiliki kesiapan untuk suatu tugas, seyogyanya tugas itu ditunda sampai siswa tersebut siap untuk mengerjakan tugas.

Kesiapan belajar mencerminkan jenis dan taraf kesiapan tersebut, misalnya dua orang siswa yang memiliki kecerdasan yang sama mungkin amat berbeda dengan kesiapan mentalnya. 
Bahan-bahan, kegiatan, dan tugas seyogyanya divariasikan agar sesuai dengan faktor kesiapan kognitif, afektif, dan psikomotor dari berbagai individu.

\section{Aspek Kesiapan}

Ada beberapa hal yang termasuk dalam aspek kesiapan, dikutip dalam buku “Belajar dan Faktor-Faktor yang Mempengaruhi" (dalam Slameto, 2013) meliputi: Kematangan, merupakan proses yang menimbulkan perubahan tingkah laku sebagai akibat dari pertumbuhan dan perkembangan. Kecerdasan, menurut J. Piaget perkembangan kecerdasan lebih lanjut akan dijelaskan sebagai berikut.

\section{Kecerdasan Menurut J. Piaget}

Beberapa jenis kecerdasan menurut J. Piaget adalah sebagai berikut: Sensori motorik period (0-2 tahun) terjadi perkembangan perbuatan sensori motorik dari yang sederhana ke relatif yang lebih kompleks. Preoperational period (2-7 tahun) anak mulai mempelajari nama-nama dari objek yang sama dengan apa yang dipelajari orang dewasa, seperti: memperoleh pengetahuan, kecakapan yang didapat belum tetap. Concrete operational (7-11 tahun) pikiran anak sudah mulai stabil, anak sudah mulai dapat berfikir tentang akibat yang mungkin terjadi dari perbuatan yang akan dilakukannya. Formal operation (lebih dari 11 tahun) kecakapan anak tidak lagi terbatas pada objek-objek yang konkret serta ia dapat berfikir dengan betul, dapat berfikir yang logis, mengerti hubungan sebab akibat.

\section{KESIMPULAN DAN SARAN}

Kesiapan belajar akan mempengaruhi hasil belajar yang akan diperoleh oleh siswa. Dan kesiapan merupakan keseluruhan kondisi seseorang yang membuatnya siap untuk memberikan respon atau jawaban di dalam proses pembelajaran. Salah satu yang mempengaruhi kesiapan belajar dan membuat tugas adalah kesiapan psikis seseorang.

Kepada siswa diharapkan mempunyai kesiapan yang matang dalam mengerjakan tugas, baik dalam mengerjakan tugas kelompok atau tugas individu, karna kesiapan siswa dalam mengerjakan tugas akan berpengaruh pada hasil yang akan diperolehnya.

\section{REFERENCES}

A. Muri Yusuf. (2007). Metodologi Penelitian. Padang: UNP Press.

Alvin C. Eurich. (1962). Former State U. Chief. The New York Times.

Djamarah, Syaiful Bahri. (2002). Strategi Belajar Mengajar. Jakarta: Rineka Cipta.

Djamarah, Syaiful Bahri. (2006). Strategi Belajar Mengajar. Jakarta: Rineka Cipta.

Gadgne Robert M. (1977). Kondisi Belajar Mengajar \& Kondisi Pembelajaran. Jakarta: Dirjen Dikti Depdikbud.

Hamid Darmadi. (2014). Metode Penelitian Pendidikan dan Sosial, Teori Konsep Dasar dan Implementasi. Bandung: Alfabeta.

Hartanto H. (2012). Keluarga Berencana dan Kontrasepsi. Jakarta: Pustaka Sinar Harapan.

Kimble, G.A. (1961). Hilgard and Marquis Conditional and Learning. New York: Apletton.

Mayer, L.H. (1982). Food Chemistry The AVI Publishing Company. California: University. 
Moh. Surya. (1997). Psikologi Pembelajaran dan Pengajaran. Bandung: PPB.

Mulyani S.N. \& Rinawati M. (2013). Keluarga Berencana dan Kontrasepsi. Yogyakarta: Nuhamedika.

Muri Yusuf. (2014). Metodologi Penelitian Kuantitatif, Kualitatuf, \& Penelitian Gabungan. Jakarta: Prenadamedia Group.

Nasution, M.N. (2005). Manajemen Mutu Terpadu:Total Quality Manajemen Edisi Kedua. Bogor: Ghalia Indonesia.

Slameto. (2013). Belajar dan Faktor-faktor yang Mempengaruhinya. Jakarta: Rineka Cipta.

Spermen Lorince. (2010). Total Quality Manajemen., Edisi Revisi. Yogyakarta: Andi.

Sudjana, Nana. (2011). Penilaian Hasil dan Proses Belajar Mengajar. Bandung: Rosdakarya.

Sugiyono. (2009). Metode Penelitian Pendidikan Kuantitatif, Kualitatif dan RED. Bandung: Alfabeta.

Sukardi. (2003). Metodologi Penelitian Pendidikan Kompetensi dan Prakteknya. Jakarta: Bumi Aksara.

Suyono \& Hariyanto. (2011). Belajar dan Pembelajaran. Bandung: Remaja Rosdakarya.

Syaiful Bahri Djamara. (2000). Konsep dan Makna Pembelajaran. Bandung: Alfabeta.

Titonegoro. (1984). Anak Supernormal dan Program Pendidikannya. Jakarta: Bina Aksara.

Tulus Winarsunu. (2003). Statistik Dalam Penelitian Psikoloi dan Pendidikan. Malang: UMM Press.

Tulus Winarsunu. (2009). Statistik Dalam Penelitian Psikologi dan Pendidikan. Malang: UMM Press. 